\title{
Pengaruh Model Pembelajaran Group Investigation Berbantuan Media Questions Card Terhadap Pemahaman Konsep \ dan Keterampilan Berpikir Kritis IPA
}

\author{
Ni Km. Inten Phramesti Putri ${ }^{1}$, Nym. Murda ${ }^{2}$, Dewa Nym. Sudana ${ }^{3}$ \\ ${ }^{123}$ Program Studi Pendidikan Dasar, Program Pascasarjana \\ Universitas Pendidikan Ganesha, Singaraja, Indonesia \\ e-mail: inten.phramesti.putri@undiksha.ac.id ${ }^{1}$, nyomanmurda@yahoo.co.id², \\ dewanyoman.sudana@undiksha.ac.id ${ }^{3}$
}

\begin{abstract}
Abstrak
Penelitian ini bertujuan untuk: 1) mengetahui pengaruh yang signifikan model pembelajaran Group Investigation berbantuan media questions card terhadap pemahaman konsep siswa kelas V SD Gugus IV Kecamatan Abiansemal, 2) mengetahui pengaruh model pembelajaran Group Investigation berbantuan media questions card terhadap keterampilan berpikir kritis IPA siswa kelas V SD Gugus IV Kecamatan Abiansemal, 3) mengetahui pengaruh model pembelajaran Group Investigation berbantuan media questions card terhadap pemahaman konsep dan keterampilan berpikir kritis IPA siswa kelas V SD Gugus IV Kecamatan Abiansemal. Penelitian ini adalah penelitian eksperimen semu (quasi experimen) dengan rancangan non-equivalent post-test only control group design. Populasi penelitian berjumlah 144 siswa kelas V yang berasal dari 6 sekolah di SD Gugus IV Kecamatan Abiansemal. Sampel ditentukan dengan teknik random sampling yaitu siswa kelas V SDN 1 Abiansemal Dauh Yeh Cani berjumlah 28 orang dan siswa kelas V SDN 1 Ayunan berjumlah 27 orang. Data penelitian dikumpulkan menggunakan metode tes dengan instrumen tes objektif untuk mengukur pemahaman konsep dan non tes dengan lembar kuesioner untuk mengukur keterampilan berpikir kritis IPA. Analisis data yang digunakan adalah statistik deskriptif dan statistik inferensial (analisis uji Manova). Hasil penelitian secara simultan menunjukkan bahwa terdapat pengaruh yang signifikan model pembelajaran Group Investigation berbantuan media questions card terhadap pemahaman konsep dan keterampilan berpikir kritis IPA dan siswa yang tidak mendapat perlakuan model pembelajaran Group Investigation berbantuan media questions card pada siswa SD Kelas V Gugus IV Kecamatan Abiansemal.
\end{abstract}

Kata Kunci : Group Investigation, IPA, Keterampilan Berpikir Kritis, media questions card, Pemahaman Konsep.

\begin{abstract}
This study is used to: 1) determine the influence of Group Investigation learning model assisted with questions card media based on the understanding of concepts in the fifth grade students at elementary school Cluster IV Abiansemal District, 2) determine the influence of Group Investigation learning model assisted with questions card media based on the critical thinking skills of science in fifth grade students at elementary school Cluster IV Abiansemal District, 3) determine the influence of Group Investigation learning model assisted with questions card media based on the understanding of concepts and critical thinking skills of science in fifth grade students at elementary school Cluster IV Abiansemal District. This research is a quasiexperimental study with non-equivalent post-test only control group design. Population of this research is 144 students in fifth grade that from elementary school students Cluster IV Abiansemal District. The sample determined by a random sampling technique with the students of SDN 1 Abiansemal Dauh Yeh Cani which is 28 person and the students of SDN 1 Ayunan which is 27 person. The data of this study were collected by using test method with the instruments an objective test to measure the understanding of concepts and description test to measure the critical thinking skills of science. The analysation data which used is statistics descriptive and statistics inferensial (Manova test). It's meant the results of research showed there is the significant influence of Group Investigation learning model assisted with questions card media based on understanding of concepts and critical thinking skills of science and the students who did not get the treatment in the fifth grade of elementary school students Cluster IV Abiansemal District.
\end{abstract}

Keywords: Critical thinking skills, Group Investigation, questins card media, science, understanding of concepts. 


\section{Pendahuluan}

Pada umumnya IPA merupakan kompetensi pengetahuan yang telah didapatkan mulai dari SD sampai ke perguruan tinggi. IPA adalah kompetensi pengetahuan yang mempelajari tentang gejala-gejala alam yang terjadi. Menurut Sudana, dkk (2016:1), "dalam pembelajaran IPA seorang guru dituntut untuk dapat mengajak anak didiknya memanfaatkan alam sekitar sebagai sumber belajar". Maksud dari pernyataan tersebut ialah alam sekitar peserta didik adalah sumber belajar yang paling dekat dengan kehidupannya sehingga mempermudah peserta didik dalam proses pembelajaran dan tidak akan habis jika digunakan.

IPA seperti yang telah dijelaskan sebelumnya merupakan salah satu kompetensi pengetahuan yang tidak hanya berpatok pada teori, melainkan praktik-praktik yang dilakukan di kelas maupun dilapangan oleh peserta didik dan dibimbing oleh guru. Selain itu materi-materi yang didapatkan dari kompetensi pengetahuan IPA juga bisa langsung dimanfaatkan dalam kehidupan nyata peserta didik. Pembelajaran IPA sangat penting diberikan di sekolah dasar, karena melalui pembelajaran IPA, peserta didik dapat dilatih untuk memiliki suatu pemahaman konsep dan keterampilan berpikir kritis dalam mengerjakan sesuatu. Untuk memiliki suatu pemahaman konsep dan keterampilan berpikir kritis, maka tugas guru ialah harus bisa merencanakan suatu pembelajaran yang inovatif dan menarik bagi siswa.

Namun pada nyatanya pembelajaran IPA di sekolah masih belum dilaksanakan dengan optimal sehingga berdampak pada proses dan hasil belajar siswa pada pembelajaran IPA. Terdapat beberapa faktor yang mempengaruhi rendahnya pemahaman konsep dan keterampilan berpikir kritis siswa selama pembelajaran berlangsung, diantaranya yaitu:

Pertama, yaitu berdasarkan hasil wawancara dengan wali kelas $V$ yaitu, selama proses pembelajaran berlangsung model pembelajaran yang digunakan masih kurang bervariasi, serta masih kurangnya pemahaman siswa tentang materi yang diberikan oleh guru, dapat dilihat dari hasil belajar yang diperoleh siswa masih cukup rendah.

Kedua, yaitu berdasarkan hasil observasi pada saat pelaksanaan pembelajaran siswa belum sepenuhnya mengikuti pembelajaran secara aktif karena siswa hanya mendengarkan penjelasan dari guru tanpa siswa ikut aktif berpartisipasi, kemudian penggunaan media pembelajaran masih belum dioptimalkan, serta keterampilan berpikir kritis siswa masih kurang, sebagian besar siswa selama mengikuti proses pembelajaran di kelas kurang memberikan respon yang baik saat guru mengajukan beberapa pertanyaan kepada siswa, serta masih ada beberapa siswa yang menggunakan jawaban temannya untuk menjawab pertanyaan guru.

Ketiga, kemudian untuk melengkapi hasil observasi dan wawancara, maka dilakukan pencatatan dokumen. Pencatatan dokumen dilakukan untuk memperkuat permasalahan yang ditemukan melalui wawancara dan observasi. Berdasarkan hasil pencatatan dokumen dapat dilihat bahwa pemahaman konsep dan keterampilan berpikir kritis IPA siswa kelas V di Gugus IV Kecamatan Abiansemal yang mencapai KKM lebih rendah yaitu $0,24 \%$ sedangkan siswa yang belum mencapai KKM yaitu sebanyak $0,76 \%$. Dengan demikian dapat disimpulkan bahwa pemahaman konsep dan keterampilan berpikir kritis IPA siswa kelas V di Gugus IV Kecamatan Abiansemal masih tergolong rendah.

Dari permasalahan yang ditemukan tersebut, sangat diperlukan suatu variasi dan inovasi dalam proses pembelajaran di kelas. Banyak hal yang dapat dilakukan untuk menciptakan suatu variasi dan inovasi belajar yang baru di dalam kelas, diantaranya guru dapat menggunakan model pembelajaran yang lebih bervariasi, penggunaan media pembelajaran yang inovatif dan kreatif sehingga dapat memicu semangat belajar serta keaktifan siswa selama proses pembelajaran di kelas berlangsung.

Maka dari itu, untuk menyikapi permasalahan tersebut, salah satu model pembelajaran yang bisa digunakan yaitu model pembelajaran Group Investigation (GI) berbantuan media pembelajaran Questions card (Kartu Pertanyaan). Model pembelajaran Group Investigation ini memiliki beberapa keunggulan yaitu mampu mengajarkan kepada peserta didik bagaimana cara menghargai dan menghormati anggota kelompok lain, mampu menghargai adanya perbedaan pendapat serta mampu mengenali bagaimana karakter dari masing-masing peserta didik dalam kelompok belajar.

Model pembelajaran Group Investigation ini akan mempertajam ingatan siswa dan melatih kerjasama siswa di dalam sebuah kelompok kecil. Penggunaan model pembelajaran Group Investigation berbantuan media questions card diharapkan dapat meningkatkan pemahaman konsep dan keterampilan berpikir kritis siswa. Pemahaman konsep memiliki peranan yang sangat penting dalam proses belajar mengajar karena merupakan suatu dasar bagi seorang siswa dapat mencapai hasil belajar yang baik. Pemahaman konsep harus ditanamkan dengan 
benar oleh seorang pendidik. Pada dasarnya konsep adalah "suatu ide yang mempersatukan fakta-fakta IPA" (Sudana dkk, 2016: 3).

Sedangkan pemahaman didapatkan dari pengalaman belajar seorang peserta didik. Warpala (dalam Linda Jayanthi, 2013) menyatakan bahwa pemahaman dapat diartikan sebagai suatu proses rekontruksi makna dan hubungan-hubungan, bukan hanya sekedar asimilasi dari pengetahuan yang telah dimiliki sebelumnya. Pemahaman konsep berhubungan erat dengan memampuan intelektual (kognitif). Selain untuk meningkatkan pemahaman konsep, model pembelajaran Group Investigation berbantuan media questions card juga diharapkan dapat meningkatkan keterampilan berpikir kritis siswa.

Keterampilan berpikir kritis merupakan "keterampilan mendasar yang dimiliki oleh manusia karena dengan memiliki keterampilan berpikir kritis, dapat mendorong seseorang untuk memandang setiap permasalahan yang dihadapi secara kritis, sehingga diperoleh suatu hal baru yang lebih baik dan lebih bermanfaat untuk kehidupannya" (Maulana, 2017:4).

Ciri-ciri orang berpikir kritis yang dikemukakan oleh Costa (dalam Maulana, 2017), antara lain yaitu mampu mendeteksi perbedaan informasi, mengumpulkan data untuk pembuktian faktual, mampu mengidentifikasi atribut-atribut benda (seperti sifat, wujud, dan sebagainya). Sebagai seorang pendidik, guru memiliki kewajiban untuk ikut serta melatih dan mengembangkan keterampilan berpikir kritis siswa, karena untuk lebih mempermudah siswa dalam menyerap dan memahami suatu pengetahuan yang didapatkan.

Stemberg (dalam John W. Santrock, 2003), menyatakan bahwa keterampilan berpikir kritis yang diperlukan dalam kehidupan sehari-hari diantaranya adalah: mengenali bahwa ada masalah, mendefinisikan masalah dengan lebih jelas, mengatasi masalah yang dapat diselesaikan bukan hanya dengan satu jawaban yang benar atau yang tujuan penyelesaiannya tidak mempunyai kriteria yang jelas, mendapatkan informasi, berpikir dalam kelompok, dan merancang pendekatan jangka panjang untuk masalah jangka panjang.

Berdasarkan uraian di atas, dapat disimpulkan bahwa keterampilan berpikir kritis merupakan keterampilan dasar yang dimiliki oleh setiap individu untuk mendorong individu dapat memandang dan memecahkan masalah dalam kehidupannya secara kritis, dan berdasarkan pada fakta yang ada.

Joyce, Weil dan Calhoun (dalam Aunurrahman, 2012), menyatakan bahwa model investigasi kelompok menawarkan agar dalam mengembangkan masalah moral dan sosial, siswa diorganisasikan dengan cara melakukan penelitian bersama atau "cooperative inquiry" terhadap masalah-masalah sosial dan moral, maupun masalah akademis.

Pandangan Tsoi, Goh, dan Chia (dalam Aunurrahman, 2012), menyatakan bahwa model investigasi kelompok secara filosofis beranjak dari paradigm konstruktivis, dimana terdapat suatu situasi yang didalamnya siswa-siswa berinteraksi dan berkomunikasi satu sama lain dengan berbagai informasi dan melakukan pekerjaan secara kolaboratif untuk menginvestigasi suatu masalah, merencanakan, mempresentasikan serta mengevaluasi kegiatan mereka.

Kajian dan pembahasan yang berkenaan dengan model ini juga dikemukakan oleh Killen (dalam Aunurrahman, 2012), yang berpandangan bahwa model investigasi kelompok merupakan cara yang langsung dan efisien untuk mengajarkan pengetahuan akademik sebagai suatu proses sosial. Untuk menerapkan model ini ada beberapa fase yang harus dilaksanakan selama proses pembelajaran berlangsung, diantaranya yaitu : "1) Mempusatkan perhatian siswa, 2) Mengidentifikasi topik dan membagi siswa ke dalam kelompok, 3) Merencanakan tugas, 4) Membuat penyelidikan, 5) Mempresentasikan tugas akhir, dan 6) Evaluasi pembelajaran". (Trianto, 2011: 78-80)

Dari beberapa penjelasan mengenai hakikat model pembelajaran investigasi kelompok (Group Investigation) dapat disimpulkan bahwa model pembelajaran investigasi kelompok ini merupakan salah satu model pembelajaran kooperatif yang melibatkan keaktifan siswa secara langsung dalam proses pembelajaran di kelas, selain itu model investigasi kelompok juga mampu menumbuhkan rasa percaya diri siswa, rasa menghargai teman antar ataupun dalam kelompok serta mengajarkan siswa untuk saling menerima perbedaan pendapat dalam proses belajar di kelas.

Model pembelajaran Group Investigation berbantuan media questions card merupakan salah satu model pembelajaran kooperatif yang mampu melibatkan keaktifan siswa secara langsung dalam proses belajar di kelas. Yang mana dalam model ini siswa akan dibagi menjadi beberapa kelompok kecil yang beranggotakan 4-6 orang dalam kelompok dengan kemampuan yang berbeda-beda dan dibagi secara heterogen. Setiap anggota kelompok dituntut agar mampu bekerjasama dengan baik, dapat menghargai perbedaan pendapat dalam kelompok. Dengan penggunaan media questions card dalam model pembelajaran ini, maka setiap 
kelompok diberikan kesempatan yang sama untuk menyajikan hasil investigasi dan analisis terhadap suatu materi atau topik permasalahan yang diberikan oleh guru. Media questions card akan membantu siswa agar lebih memahami konsep-konsep dalam pembelajaran dan mampu melatih keterampilan berpikir kritis siswa dalam kelompok kecilnya.

Untuk menambah refrensi dan pendukung penelitian ini, penulis mencari hasil penelitian yang relevan. Hasil penelitian lain yang menggunakan model pembelajaran Group Investigation dilakukan oleh Setia Wardana (2013) menyatakan bahwa penerapan model pembelajaran Group Investigation berbantuan asesmen proyek berpengaruh terhadap hasil belajar IPA siswa kelas V SD Gugus III Tampaksiring. I Ketut Budiastra, dkk. (2015), menyatakan bahwa penerapan model pembelajaran Group Investigation berpengaruh terhadap keterampilan berpikir kritis IPA siswa kelas V SD Gugus VII Kecamatan Tejakula Tahun Pelajaran 2013/2014. Gusti Ayu Ikka Pramesti, dkk. (2013) menyatakan bahwa penerapan model pembelajaran Group Investigation berpengaruh terhadap pemahaman konsep IPA siswa kelas V SD di Gugus VI Kecamatan Sukasada Tahun Pelajaran 2013/2014.

Berdasarkan permasalahan yang ditemukan yang menjadi pokok permasalahannya yaitu rendahnya pemahaman konsep dan keterampilan berpikir kritis siswa pada pelajaran IPA dan tentu permasalahan tersebut harus dicarikan solusi pemecahan masalahnya. Maka dari itu dalam penelitian ini, peneliti akan mencoba mencari solusi terhadap permasalahan yang terjadi dengan menggunakan model pembelajaran Group Investigation berbantuan media questions card dalam proses pembelajaran di kelas untuk mengetahui ada atau tidaknya pengaruh pemahaman konsep dan keterampilan berpikir kritis siswa pada pelajaran IPA setelah digunakannya model tersebut. Sesuai dengan tujuan dalam penelitian ini adalah untuk mengetahui secara simultan pengaruh yang signifikan antara kelompok siswa yang dibelajarkan menggunakan model pembelajaran Group Investigation berbantuan media questions card terhadap pemahaman konsep dan keterampilan berpikir kritis IPA dengan kelompok siswa yang dibelajarkan menggunakan model pembelajaran konvensional pada siswa kelas V SD Gugus IV Kecamatan Abiansemal.

\section{Metode}

Penelitian ini dilaksanakan di SD Gugus IV Kecamatan Abiansemal yang terdiri dari 6 sekolah. Jenis penelitian ini adalah eksperimen semu atau quasi eksperiment. Penelitian ini menggunakan rancangan non equivalent post-test only control group design. Secara prosedural mengikuti pola seperti yang ditunjukkan pada Tabel 1 berikut.

Tabel 1.Rancangan Eksperimen

\begin{tabular}{llc}
\hline Eksperimen $(\mathrm{KE})$ & $\mathrm{X}$ & $\mathrm{O}_{1}$ \\
\hline Kontrol $(\mathrm{KK})$ & - & $\mathrm{O}_{2}$ \\
\hline & & Sumber: Gall, et al. (dalam Agung, 2014:163)
\end{tabular}

Populasi pada penelitian ini adalah semua siswa kelas V di SD Gugus IV Kecamatan Abiansemal yang berjumlah 144 siswa. Sebelum menetapkan sampel, terlebih dahulu dilakukan uji kesetaraan nilai pemahaman konsep dan keterampilan berpikir kritis IPA siswa kelas $V$ di Gugus IV Kecamatan Abiansemal. Untuk mengetahui apakah kemampuan masing- masing siswa kelas V di SD setara atau belum. Uji kesetaraan dilakukan dengan menggunakan ANAVA satu jalur. Berdasarkan hasil analisis dengan ANAVA A pada taraf signifikansi 5\%, diperoleh nilai $F_{\text {hit }}$ sebesar 1,36 sedangkan nilai $F_{\text {tab }}$ pada $\mathrm{db}_{\text {antar }}=5$ dan $\mathrm{db}_{\text {dal }}=138$ yaitu diperoleh $\mathrm{F}_{\text {tabel }}$ sebesar 2,28. Dengan demikian, maka terlihat $F_{\text {hit }}<F_{\text {tab }}(1,36<2,28)$, sehingga $H_{1}$ ditolak dan $H_{0}$ diterima. Dari pernyataan tersebut maka dapat ditarik kesimpulan bahwa pemahaman konsep dan keterampilan berpikir kritis IPA siswa V SD di Gugus IV Kecamatan Abiasemal setara.

Setelah setara, selanjutnya ditentukan sampel penelitian dengan teknik group random sampling diperoleh kelas V SDN 1 Abiansemal Dauh Yeh Cani sebagai kelas eksperimen yang berjumlah 28 siswa dan kelas V SDN 1 Ayunan sebagai kelas kontrol yang berjumlah 27 siswa. Data penelitian ini dikumpulkan dengan metode tes.

Instrumen pengumpulan data menggunakan instrumen tes objektif untuk mengukur pemahaman konsep dan tes uraian untuk mengukur keterampilan berpikir kritis IPA. Data yang telah dikumpulkan kemudian dianalisis menggunakan teknik analisis statistik deskriptif dan teknik analisis inferensial (uji Manova). 
Selanjutnya dilakukan uji prasyarat yaitu berupa uji normalitas sebaran data, uji homogenitas varians, dan uji korelasi antar variabel terikat. Uji prasyarat ini dilakukan sebelum melakukan uji hipotesis. Kemudian dilanjutkan dengan uji analisis Manova. Analisis deskriptif digunakan adalah mean, median, modus dan standar deviasi.

Sebelum melakukan uji hipotesis maka dilakukan beberapa uji prasyarat yaitu. 1) Uji Normalitas Sebaran Data dengan kreteria pengujian data berdistribusi normal jika angka singnifikan (sig.) > 0,05. 2) Uji Homogenitas Varians dengan kreteria data berdistribusi homogenitas jika angka singnifikan (sig.) > 0,05. 3) Uji Korelasi Antar Variabel terikat dengan kriteria hasil uji menunjukkan kedua variabel terikat tidak berkorelasi pada taraf signifikansi $5 \%$. Setelah selesai melakukan uji prasyarat maka dilakukan uji hipotesis dengan kreteria jika nilai $($ sig, $)<0,05$.

Hipotesis dalam penelitian ini adalah secara simultan terdapat pengaruh yang signifikan pemahaman konsep dan keterampilan berpikir kritis IPA antara kelompok siswa yang dibelajarkan dengan model pembelajaran Group Investigation berbantuan media questions card dan kelompok siswa yang tidak dibelajarkan dengan model pembelajaran Group Investigation berbantuan media questions card pada siswa kelas V Sekolah Dasar di Gugus IV Kecamatan Abiansemal. Pengujian hipotesis ini dilakukan dengan uji Manova berbantuan SPSS 17 for Windows pada taraf signifikansi 0,05.

\section{Hasil dan Pembahasan}

Data hasil penelitian yang diperoleh secara simultan yaitu pemahaman konsep dan keterampilan berpikir kritis IPA siswa yang dibelajarkan dengan model pembelajaran Group Investigation berbantuan media questions card dan siswa yang tidak dibelajarkan dengan model pembelajaran Group Investigation berbantuan media questions card. Rangkuman hasil analisis statistik deskriptif disajikan pada Tabel 2 berikut.

Tabel 2. Rangkuman Hasil Analisis Deskriptif

\begin{tabular}{lcccc}
\hline & Variabel & \multicolumn{2}{c}{ PK } & \multicolumn{2}{c}{ KBK } \\
\hline Statistik & $\mathrm{Y} 1$ & $\mathrm{Y} 2$ & $\mathrm{Y} 1$ & $\mathrm{Y} 2$ \\
\hline $\mathrm{N}$ & 28 & 28 & 27 & 27 \\
\hline Mean & 19,25 & 14,30 & 94,04 & 68,85 \\
\hline Median & 19,7 & 13,2 & 94,02 & 67,2 \\
\hline Modus & 20,3 & 10,1 & 97,5 & 63 \\
\hline Standar Deviasi & 4,75 & 4,65 & 6,49 & 6,48 \\
\hline
\end{tabular}

Setelah hasil analisis statistik deskriptif didapatkan, maka selanjutnya dilakukan uji prasyarat yang meliputi uji normalitas sebaran data, uji homogenitas varians, dan uji korelasi antar variabel terikat.

Uji normalitas sebaran data diuji dengan teknik Kolmogrov-Smirnov dan Shapiro-Wilk menggunakan bantuan SPSS 17.0 for windows pada taraf signifikansi 0,05 diperoleh hasil seperti yang disajikan pada tabel 3 .

Tabel 3. Uji Normalitas Sebaran Data

\begin{tabular}{llllllll}
\hline Pemahaman & Eksperimen & .111 & 28 & $.200^{*}$ & .953 & 28 & .237 \\
Konsep & Kontrol & .124 & 27 & $.200^{*}$ & .932 & 27 & .078 \\
Keterampilan & Eksperimen & .105 & 28 & $.200^{*}$ & .955 & 28 & .261 \\
Berpikir Kritis & Kontrol & .114 & 27 & $.200^{*}$ & .955 & 27 & .276 \\
\hline
\end{tabular}

Setelah diketahui seluruh sebaran data berdistribusi normal, maka dilanjutkan dengan uji homogenitas varians. Uji homogenitas varians menggunakan uji Test of Homogeneity of Variance bantuan program SPSS 17.0 for windows pada taraf signifikan 0,05 dan diperoleh hasil seperti yang disajikan pada tabel 4 . 
TSCJ, Vol 1 No 2, Tahun 2018

p-ISSN : 2615-4692 e-ISSN : 2615-6105

Tabel 4. Uji Homogenitas Varians

\begin{tabular}{|c|c|c|c|c|c|}
\hline \multirow[t]{4}{*}{ Pemahaman Konsep } & Based on Mean & .038 & 1 & 53 & .846 \\
\hline & Based on Median & .015 & 1 & 53 & .902 \\
\hline & $\begin{array}{l}\text { Based on Median and with } \\
\text { adjusted df }\end{array}$ & .015 & 1 & 52.997 & .902 \\
\hline & Based on trimmed mean & .025 & 1 & 53 & .875 \\
\hline \multirow{4}{*}{$\begin{array}{l}\text { Keterampilan Berpikir } \\
\text { Kritis }\end{array}$} & Based on Mean & .026 & 1 & 53 & .873 \\
\hline & Based on Median & .036 & 1 & 53 & .851 \\
\hline & $\begin{array}{l}\text { Based on Median and with } \\
\text { adjusted df }\end{array}$ & .036 & 1 & 52.595 & .851 \\
\hline & Based on trimmed mean & .028 & 1 & 53 & .868 \\
\hline
\end{tabular}

Setelah uji homogenitas dilakukan diperoleh variabel pemahaman konsep dan keterampilan berpikir kritis IPA siswa homogen. Kemudian dilanjutkan dengan uji korelasi antar variabel terikat. Uji korelasi antar variabel terikat dilakukan untuk mengetahui hubungan/korelasi yang signifikan antar variabel. Jika tidak ada hubungan/korelasi yang cukup tinggi, berarti tidak ada aspek yang sama diukur pada variabel tersebut dengan kata lain kedua variabel tersebut berbeda.pengujian korelasi antar variabel terikat menggunakan uji product moment pada taraf signifikansi 0,05 diperoleh hasil pengujian seperti pada tabel 5 berikut.

Tabel 5. Uji Korelasi Antar Variabel Terikat dengan Uji Product Moment

\begin{tabular}{clcccl} 
No & Kelompok Data & $r_{x y}$ hitung & $r_{x y}$ tabel & Keterangan \\
\hline 1 & $\begin{array}{l}\text { Korelasi antar Variabel } \\
\text { Terikat Kelompok }\end{array}$ & 0,04 & 0,388 & $\begin{array}{l}\text { Tidak } \\
\text { berkorelasi }\end{array}$ \\
& $\begin{array}{l}\text { Eksperimen } \\
\text { Korelasi antar Variabel } \\
\text { Terikat Kelompok Kontrol }\end{array}$ & 0,18 & & 0,396 & $\begin{array}{l}\text { Tidak } \\
\text { berkorelasi }\end{array}$ \\
\hline
\end{tabular}

Berdasarkan Tabel 5 menunjukkan bahwa antar variabel terikat pada kelas control dan kelas eksperimen tidak berkorelasi. Setelah semua uji prasyarat dilakukan, maka dilanjutkan dengan pengujian analisis Manova dengan bantuan SPSS 17.0 for windows pada taraf signifikansi 0,05 seperti pada tabel 6 berikut.

Tabel 6. Uji Analisis dengan Manova

\begin{tabular}{|c|c|c|c|c|c|c|}
\hline & Effect & Value & $\mathrm{F}$ & Hypothesis df & Error df & Sig. \\
\hline \multirow{4}{*}{ Intercept } & Pillai's Trace & .994 & $4268.026^{a}$ & 2.000 & 52.000 & .000 \\
\hline & Wilks' Lambda & .006 & $4268.026^{a}$ & 2.000 & 52.000 & .000 \\
\hline & Hotelling's Trace & 164.155 & $4268.026^{a}$ & 2.000 & 52.000 & .000 \\
\hline & $\begin{array}{c}\text { Roy's Largest } \\
\text { Root }\end{array}$ & 164.155 & $4268.026^{a}$ & 2.000 & 52.000 & .000 \\
\hline \multirow{4}{*}{ Y } & Pillai's Trace & .796 & $101.537^{\mathrm{a}}$ & 2.000 & 52.000 & .000 \\
\hline & Wilks' Lambda & .204 & $101.537^{\mathrm{a}}$ & 2.000 & 52.000 & .000 \\
\hline & Hotelling's Trace & 3.905 & $101.537^{\mathrm{a}}$ & 2.000 & 52.000 & .000 \\
\hline & $\begin{array}{l}\text { Roy's Largest } \\
\text { Root }\end{array}$ & 3.905 & $101.537^{\mathrm{a}}$ & 2.000 & 52.000 & .000 \\
\hline
\end{tabular}

Hasil penelitian ini mendeskripsikan data yang dikelaskan untuk menganalisis kecenderungan: (1) pemahaman konsep IPA siswa yang dibelajarkan menggunakan model pembelajaran Group Investigation berbantuan media questions card; (2) keterampilan berpikir kritis IPA siswa yang dibelajarkan menggunakan model pembelajaran Group Investigation berbantuan media questions card; (3) pemahaman konsep IPA siswa yang tidak dibelajarkan 
menggunakan model pembelajaran Group Investigation berbantuan media questions card; (4) keterampilan berpikir kritis IPA siswa yang tidak dibelajarkan menggunakan model pembelajaran Group Investigation berbantuan media questions card.

Pertama, hasil penelitian ini menunjukkan terdapat pengaruh yang signifikan model pembelajaran Group Investigation berbantuan media questions card terhadap pemahaman konsep IPA siswa dengan siswa yang tidak dibelajarkan menggunakan model pembelajaran Group Investigation berbantuan media questions card. Hasil uji hipotesis dalam penelitian ini terbukti bahwa pemahaman konsep IPA siswa yang dibelajarkan menggunakan model pembelajaran Group Investigation berbantuan media questions card hasilnya lebih baik dibandingkan dengan pemahaman konsep siswa yang tidak dibelajarkan menggunakan model pembelajaran Group Investigation berbantuan media questions card. Berdasarkan data hasil analisis Manova dengan bantuan program SPSS 17 for windows diperoleh nilai signifikan pemahaman konsep pada kolom Corrected Model sebesar 0,000 dan lebih kecil dari nilai signifikansi 0,05 .

Perbedaan dari pencapaian pemahaman konsep antara siswa yang dibelajarkan menggunakan model pembelajaran Group Investigation berbantuan media questions card dengan siswa yang tidak dibelajarkan menggunakan model pembelajaran Group Investigation berbantuan media questions card dapat dijelaskan penyebabnya secara teoritik dimana keduanya memiliki karakteristik yang berbeda dilihat dari hakikat pengertiannya masing-masing. Seperti yang djelaskan oleh Joyce, Weil dan Calhoun (dalam Aunurrahman, 2012), model investigasi kelas (Group Investigation) lebih menekankan kepada kerjasama peserta didik dalam menyelesaikan tugas-tugas kelas. Dengan adanya kerjasama dalam kelompok akan berdampak positif bagi masing-masing siswa dalam kelompok tersebut, karena kerjasama kelompok dapat memberikan peluang untuk mereka saling bertukar informasi maupun pengetahuan yang dimiliki.

Model pembelajaran Group Investigation berbantuan media questions card merupakan salah satu model pembelajaran kooperatif yang mampu melibatkan keaktifan siswa secara langsung dalam proses belajar di kelas. Yang mana dalam model ini siswa akan dibagi menjadi beberapa kelompok kecil yang beranggotakan 4-6 orang dalam kelompok dengan kemampuan yang berbeda-beda dan dibagi secara heterogen. Tujuan dipergunakannya heterogenitas dalam kelompok agar setiap siswa mampu saling berbagi dan betukar informasi dengan teman kelompoknya. Seperti halnya dalam satu kelompok tentu ada seorang siswa yang memiliki kemampuan lebih dibandingkan temannya yang lain dalam satu kelompok, siswa tersebut tentu harus berbagi ilmu pengetahuan yang dimiliki dengan anggota lain yang memiliki kemampuan kurang. Dengan demikian, siswa yang kemampuannya kurang akan termotivasi untuk belajar bersama dalam kelompok demi terwujudnya kerjasama yang solid dalam kelompok tersebut. Setiap anggota kelompok dituntut agar mampu bekerjasama dengan baik, dapat menghargai perbedaan pendapat dalam kelas.

Peran guru dalam model ini menuntut agar proses pembelajaran di kelas dapat berpusat pada siswa (student center) karena sesuai dengan kurikulum yang berlaku saat ini, seorang guru tidak diperkenankan untuk memberikan penjelasan materi yang terlalu banyak dan padat kepada siswa, maka dari itu seorang guru harus berinisiatif untuk menggunakan suatu media pembelajaran inovatif di kelas guna meningkatkan ketertarikan siswa selama mengikuti pembelajaran serta mampu melatih dan mempertajam ingatan siswa. Dengan penggunaan media questions card dalam model pembelajaran ini, maka setiap kelas diberikan kesempatan yang sama untuk menyajikan hasil investigasi dan analisis terhadap suatu materi atau topik permasalahan yang diberikan oleh guru.

Hasil penelitian ini sejalan dengan hasil penelitian yang telah dilakukan oleh Gusti Ayu Ikka Pramesti, dkk. (2013), yang menunjukkan bahwa penerapan model pembelajaran Group Investigation memiliki pengaruh yang tinggi terhadap pemahaman konsep IPA siswa kelas $\mathrm{V}$ SD di Gugus VI Kecamatan Sukasada Tahun Pelajaran 2013/2014.

Kedua, hasil penelitian ini menunjukkan terdapat pengaruh yang signifikan model pembelajaran Group Investigation berbantuan media questions card terhadap keterampilan berpikir kritis IPA siswa dengan siswa yang tidak dibelajarkan menggunakan model pembelajaran Group Investigation berbantuan media questions card. Hasil uji hipotesis dalam penelitian ini terbukti bahwa keterampilan berpikir kritis IPA siswa yang dibelajarkan menggunakan model pembelajaran Group Investigation berbantuan media questions card hasilnya lebih baik dibandingkan dengan pemahaman konsep siswa yang tidak dibelajarkan menggunakan model pembelajaran Group Investigation berbantuan media questions card. Berdasarkan data hasil analisis Manova dengan bantuan program SPSS 17 for windows 
diperoleh nilai signifikan keterampilan berpikir kritis pada kolom Corrected Model sebesar 0,000 dan lebih kecil dari nilai signifikansi 0,05 .

Model pembelajaran Group Investigation berbantuan media questions card pada proses pembelajarannya di kelas lebih menekankan pada aktivitas belajar dengan kelompok kecil. Sejalan dengan yang dikemukakan oleh Killen (dalam Aunurrahman, 2012), yang berpandangan bahwa model investigasi kelas merupakan cara yang langsung dan efisien untuk mengajarkan pengetahuan akademik sebagai suatu proses sosial. Model ini juga akan mampu menumbuhkan kehangatan antar pribadi, kepercayaan, rasa hormat terhadap aturan dan kebijakan, kemandirian dalam belajar serta hormat terhadap harkat dan martabat orang lain.

Joyce dan Weil (dalam Aunurrahman, 2012), menyimpulkan model investigasi kelas memiliki kelebihan dan komprehensivitas, dimana model ini memadukan penelitian akademik, integrasi sosial, dan proses belajar sosial. Model ini juga dapat dipergunakan dalam segala areal subjek, dengan seluruh tingkatan usia. Seperti yang telah dijelaskan sebelumnya bahwa model Group Investigation berbantuan media questions card merupakan salah satu model kooperatif yang dapat digunakan oleh guru dalam proses pembelajaran.

Hasil penelitian ini sejalan dengan hasil penelitian yang dilakukan oleh I Ketut Budiastra, dkk. (2015), yang menunjukkan bahwa penerapan model pembelajaran Group Investigation berpengaruh tinggi terhadap keterampilan berpikir kritis IPA siswa kelas V SD Gugus VII Kecamatan Tejakula Tahun Pelajaran 2013/2014.

Ketiga, hasil penelitian ini bertujuan untuk mengetahui pengaruh model pembelajaran Group Investigation berbantuan media questions card terhadap pemahaman konsep dan keterampilan berpikir kritis IPA siswa dengan siswa yang tidak dibelajarkan menggunakan model pembelajaran Group Investigation berbantuan media questions card dilakukan analisis Manova dengan bantuan program SPSS 17 for windows menunjukkan bahwa, didapatkan nilai signifikan Pillai's Treace, Wilks'Lambda, Hotelling's Trice, dan Roy's Larget Root sebesar 0,000 dan lebih kecil dari 0,05. Sehingga dapat disimpulkan bahwa hipotesis nol (H0) ditolak dan hipotesis alternatif $(\mathrm{Ha})$ diterima. Dengan kata lain semua nilai dari Pillai's Treace, Wilks'Lambda, Hotelling's Trice, dan Roy's Larget Root signifikan. Dengan demikian terdapat pengaruh yang signifikan model pembelajaran Group Investigation berbantuan media questions card terhadap pemahaman konsep dan keterampilan berpikir kritis IPA siswa kelas V SD Gugus IV Kecamatan Abiansemal.

Berdasarkan hasil penelitian menunjukkan bahwa terdapat hubungan positif antara pemahaman konsep dan keterampilan berpikir kritis yang dimiliki oleh siswa. Dengan demikian pencapaian pemahaman konsep dan keterampilan berpikir kritis siswa haruslah sejalan dan seimbang selama proses pembelajaran berlangsung. Karena pada dasarnya pemahaman konsep adalah suatu dasar bagi seorang siswa dapat mencapai hasil belajar yang baik. Pemahaman konsep harus ditanamkan dengan benar oleh seorang pendidik. Pada dasarnya konsep adalah "suatu ide yang mempersatukan fakta-fakta IPA" (Sudana dkk, 2016: 3). Sejalan dengan beberapa pendapat sebelumnya, Purwanto (dalam Dwi Ariantari, 2013) menyatakan bahwa pemahaman adalah tingkat kemampuan yang mengharapkan pebelajar mampu memahami arti atau konsep, situasi, serta fakta yang diketahuinya.

Sedangkan keterampilan berpikir kritis merupakan "keterampilan mendasar yang dimiliki oleh manusia karena dengan memiliki keterampilan berpikir kritis, dapat mendorong seseorang untuk memandang setiap permasalahan yang dihadapi secara kritis, sehingga diperoleh suatu hal baru yang lebih baik dan lebih bermanfaat untuk kehidupannya" (Maulana, 2017:4). Ciri-ciri orang berpikir kritis yang dikemukakan oleh Costa (dalam Maulana, 2017), antara lain yaitu mampu mendeteksi perbedaan informasi, mengumpulkan data untuk pembuktian faktual, mampu mengidentifikasi atribut-atribut benda (seperti sifat, wujud, dan sebagainya).

Hasil penelitian ini sejalan dengan hasil penelitian yang dilakukan oleh Setia Wardana (2013), yang menunjukkan bahwa penerapan model pembelajaran Group Investigation berbantuan asesmen proyek berpengaruh tinggi terhadap hasil belajar IPA siswa kelas V SD Gugus III Tampaksiring. Selain itu, penelitian ini juga sejalan dengan hasil penelitian yang dilakukan oleh I Ketut Budiastra, dkk. (2015), yang menunjukkan bahwa penerapan model pembelajaran Group Investigation berpengaruh tinggi terhadap keterampilan berpikir kritis IPA siswa kelas V SD Gugus VII Kecamatan Tejakula Tahun Pelajaran 2013/2014.

Maka dari itu sesuai dengan hasil penelitian dan penelitian lain yang relevan telah menunjukkan bahwa dengan menerapkan model pembelajaran Group Investigation sangat mampu meningkatkan pemahaman konsep dan keterampilan berpikir kritis IPA siswa. Bisa dilihat bahwa antara pemahaman konsep dan keterampilan berpikir kritis siswa memiliki hubungan yang sangat erat. Artinya bahwa semakin tinggi pemahaman konsep yang dimiliki 
siswa, semakin baik pula keterampilan berpikir kritis yang dimiliki oleh siswa. Pendidik memiliki peranan yang sangat penting selama proses pembelajaran berlangsung untuk mengimplementasikan model pembelajaran Group Investigation berbantuan media questions card agar dapat dipahami dengan baik oleh siswa serta mampu meningkatkan pemahaman konsep dan keterampilan berpikir kritis

4.

\section{an dan Saran}

Simpul

Berdasarkan hasil penelitian dan pembahasan, dapat ditarik simpulan bahwa: 1) terdapat pengaruh yang signifikan model pembelajaran Group Investigation berbantuan media questions card terhadap pemahaman konsep siswa kelas V SD Gugus IV Kecamatan Abiansemal, 2) terdapat pengaruh yang signifikan model pembelajaran Group Investigation berbantuan media questions card terhadap keterampilan berpikir kritis IPA siswa kelas V SD Gugus IV Kecamatan Abiansemal, 3) secara simultan, terdapat pengaruh yang signifikan model pembelajaran Group Investigation berbantuan media questions card terhadap pemahaman konsep dan keterampilan berpikir kritis IPA siswa kelas V SD Gugus IV Kecamatan Abiansemal.

Berdasarkan temuan - temuan dalam penelitian ini, dapat disampaikan saran - saran sebagai berikut.

Pertama, kepada Siswa di SD tempat penelitian maupun di SD lain agar lebih aktif dalam mengikuti pembelajaran dan terus mengembangkan pemahamannya dengan membangun sendiri pengetahuan tersebut melalui pengalaman.

Kedua, kepada Guru dalam membelajarkan IPA di SD agar lebih inovatif dalam memilih model pembelajaran dan media pembelajaran yang akan diterapkan pada proses pembelajaran. Sehingga pembelajaran lebih efektif dan menarik, tidak monoton, serta dapat meningkatkan pemahaman konsep dan kemampuan pemecahan masalah siswa.

Ketiga, Kepada Kepala Sekolah disarankan agar dapat menciptakan kondisi yang mampu mendorong para guru untuk mencoba menerapkan model pembelajaran Group Investigation berbantuan media questions card dalam pembelajaran IPA khususnya dan mata pelajaran lain pada umumnya dalam upaya meningkatkan pemahaman konsep dan keterampilan berpikir kritis.

Keempat, kepada Peneliti Lain yang berminat untuk mengadakan penelitian lebih lanjut tentang model pembelajaran Group Investigation berbantuan media questions card dalam bidang ilmu lainnya. Penelitian ini sebagai bahan pertimbangan untuk perbaikan dan penyempurnaan penelitian yang akan dilaksanakan.

\section{Daftar Pustaka}

Aunurrahman. 2012. Belajar dan Pembelajaran. Bandung: Alfabeta.

Ayu Ikka Pramesti, Gusti, dkk. 2013. "Pengaruh Model Pembelajaran Group Investigation terhadap Pemahaman Konsep IPA Siswa SD" ejournal PGSD Universitas Pendidikan Ganesha Mimbar Pgsd, Vol 2, No. 1, Tahun 2013. Tersedia pada: http://ejournal.undiksha.ac.id/index.php/JJPGSD/article/view/3828. Diakses tanggal 26 Maret 2019.

Budiastra, I Ketut, dkk. 2015. "Pengaruh Model Pembelajaran Group Investigations terhadap Keterampilan Berpikir Kritis dalam Pembelajaran IPA" ejournal PGSD Universitas Pendidikan Ganesha Mimbar Pgsd, Vol 3, No. 1, Tahun 2015. Tersedia pada: http://ejournal.undiksha.ac.id/index.php/JJPGSD/article/view/4812. Diakses tanggal 26 Maret 2019.

Dwi Ariantari, Ni Md, dkk. 2013. "Pengaruh Model Pembelajaran Tandur terhadap Pemahaman Konsep IPA Siswa Kelas IV Sekolah Dasar Gugus VI Kecamatan Buleleng". Ejournal PGSD Universitas Pendidikan Ganesha Mimbar Pgsd, Vol. 1, No. 1, Tahun 2013. Tersedia pada: https://ejournal.undiksha.ac.id/index.php/JJPGSD/article/view/893. Diakses tanggal 26 Maret 2019.

John W. Santrock. 2003. Adolescence Perkembangan Remaja. Jakarta: Erlangga. 
Linda Jayanthi, Ni Wayan, dkk. 2013. "Pengaruh Metode PQRST terhadap Pemahaman Konsep IPA Siswa Kelas V SD di Gugus V Kecamatan Kediri". Ejournal PGSD Universitas Pendidikan Ganesha Mimbar Pgsd, Vol. 1, No. 1, Tahun 2013. Tersedia pada: https://ejournal.undiksha.ac.id/index.php/JJPGSD/article/view/751. Diakses tanggal 25 Maret 2019.

Maulana. 2017. Konsep Dasar Matematika dan Pengembangan Kemampuan Berpikir KritisKreatif. Sumedang: UPI Sumedang Press.

Setia Wardana, I Wayan. 2013. "Pengaruh Model Pebelajaran Group Investigation Berbantuan Asesmen Proyek Terprestasi Belajar IPA Siswa Kelas V Sekolah Dasar Gugus III Tampaksiring". Ejournal PGSD Universitas Pendidikan Ganesha Mimbar Pgsd, Vol 1, No. 1, Tahun 2013. Tersedia pada: https://ejournal.undiksha.ac.id/index.php/JJPGSD/\%20article/view/1196._Diakses tanggal 18 Januari 2019.

Sudana, Dewa Nyoman, dkk. 2016. Pendidikan IPA SD. Singaraja: Universitas Pendidikan Ganesha.

Trianto. 2011. Mendesain Model Pembelajaran Inovatif Progresif. Edisi Ke-4. Jakarta: Kencana. 